\title{
Low-Value Maize and Wheat By-Products as a Source of Ferulated Arabinoxylans
}

\author{
Claudia Berlanga-Reyes ${ }^{1}$, Elizabeth Carvajal-Millan'1, \\ Guillermo Niño-Medina4, Agustín Rascón-Chu², \\ Benjamín Ramírez-Wong ${ }^{3}$ and Elisa Magaña-Barajas ${ }^{3}$ \\ Centro de Investigación en Alimentación y Desarrollo, \\ A.C. Hermosillo, Sonora, \\ ${ }^{1}$ Laboratorio de biopolímeros, CTAOA, \\ ${ }^{2}$ Laboratorio de biotecnología. CTAOV, \\ ${ }^{3}$ Departamento de Investigación y Posgrado en Alimentos, Universidad de Sonora, \\ 4Facultad de Agronomía, Universidad Autónoma de Nuevo León, \\ 1,2,3,4México
}

\section{Introduction}

The major polymers in the cell walls are cellulose (25-35\%), hemicelluloses $(40-50 \%)$ and lignin $(7-10 \%)$. Both cellulose and hemicelluloses function as structural supporting materials in the cell walls; cellulose has a high tensile strength and gives rigidity to the walls, whereas hemicelluloses impart elasticity to the structure by cross-linking cellulose micro fibrils (Ishii, 1997). Xylans occur as the most common hemicelluloses, and after cellulose they are the second most abundant polysaccharides in the plant kingdom.

Arabinoxylans (AX) are hemicelluloses built up of pentose sugars, mostly arabinose and xylose residues, and are therefore often referred to as pentosans (Izydorczyk \& Biliaderis, 1995). AX consist of backbone chains of $\beta(1,4)$ linked-linked D-xylopyranosyl units to which aL arabinofuranosyl substituents are attached through O-2 and/or O-3 (Fincher \& Stone, 1974). Some of the arabinose residues are ester linked on (O)-5 to ferulic acid (FA) (3-methoxy, 4 hydroxy cinnamic acid) (Smith \& Hartley, 1983). AX are mayor dietary fiber components of many cereals like wheat, rye, corn, barley, oat, rice and sorghum (Fincher \& Stone, 1974). AX are classified into water-extractable (WEAX) and water-unextractable AX (WUAX). The WUAX present a combination of no covalent interactions and covalent bonds with other cell walls components, such as proteins, cellulose and lignin (Andrewartha et al., 1979).

AX can be isolated by water and by alkali extraction (Cui et al., 2001). The extractability of these polysaccharides is based on the conformational aggregation, the covalent ester bonds between ferulic acid and other components such as lignin, the degree, and substitution patter of arabinoses at side chain, and nature of physical entanglement. Once extracted AX form highly viscous solutions with gelling capacity by covalent cross-linking through dimerization of ferulic acid substituents under oxidative conditions (e.g., use of enzymatic free radical generating agents as laccase and peroxidase $\mathrm{H}_{2} \mathrm{O}_{2}$ ) (Geissman et al., 1973; Figueroa Espinoza et al., 1998). Diferulic acids (di-FA) and triferulic acid (tri-FA) 
(Vansteenkiste et al., 2004; Carvajal-Millan et al., 2005a) have been identified as covalently cross-linked structures in AX gels.

AX gels present interesting properties like neutral taste and odor, high water absorption capacity and absence of $\mathrm{pH}$ or electrolyte susceptibility (Izydorczyk \& Biliaderis, 1995). Interest on AX and AX gels has increased in the last years and new information on their sources and applications are being reported. Recuperation of AX from cereal by-products of the food industry has been reported (Niño-Medina (2009), b; Carvajal-Millan et al., 2007) and would offer new advantages for future industrial applications of this biomolecule.

Maize and wheat are important sources of food in Mexico. They are used to obtain different food products such as cereal breakfasts, bread, tortilla, among others. During processing, maize and wheat generate high amounts of low-value by products. In the past, Mesoamerican Indians learned that wood ashes facilitated maize cooking, the removal of the hard outer covering, and improved the quality of the resulting material. We now know that this process also releases the bound niacin in the maize into a readily available form. Thus, the population did not suffer the ravages of what we now call pellagra. In Mexico, this alkali cooking, called 'nixtamalization' (from the Nahuatl nixtli=ashes and tamalli=dough) is widely used to improve the maize nutritional value.

Maize nixtamalization is important in Mexico as half of the total volume of consumed food is maize, which provides approximately $50 \%$ of the energy intake, this proportion being even greater for lower income groups. Nixtamalization consists of cooking maize grains in a lime solution, soaking for 2-8 hours and washing them by hand to remove the pericarp. The product obtained is then ground to obtain nixtamal (dough or masa) used to prepare a variety of products, tortilla being the most popular one. The nixtamalization process degrades and solubilizes maize cell wall components and this facilitates pericarp removal. As a matter of fact, the 'nejayote' (maize nixtamalization waste water) contains, in general, more than $60 \%$ of non-starch polysaccharides. These alkali-soluble non-cellulosic cell wall polysaccharides present in maize pericarp (mainly arabinoxylan) show interesting functional properties as thickeners, stabilizers, emulsifiers and film and gel formers.

The nejayote obtained from nixtamalization is highly alkaline waste water, with high chemical and biological oxygen demands and is considered an environmental pollutant. A typical maize nixtamalization facility processing $50 \mathrm{~kg}$ of maize every day uses over 75 liters of water per day and generates nearly the equivalent amount of alkaline waste water in 24 hours. Thus, alternatives of nejayote residues utilization in Mexico are needed. NiñoMedina et al., (2009) recently reported that nejayote can be a novel source of AX. During the milling process of maize and wheat the starchy endosperm is isolated with the minimum contamination by peripheral layers of the grain (i.e. aleurone layer and bran).

Maize and wheat bran are by-products of the commercial flour industry in Mexico. Because of the high volume of maize and wheat bran produced in Mexico, these residues are becoming into potential sources of added-value biomolecules as AX for the food industry. Maize bran contains heteroxylans (approximately 50\%), cellulose (approximately 20\%) and phenolic acids (approximately 4\%, mainly ferulic and diferulic acid) (Saulnier et al. 1995a). Starch (9-23\%), proteins (10-13\%), oil (2-3\%) and ash (2\%) are also present in maize bran (Hespell, 1998). The heteroxylans portion of maize bran can be extracted with alkaline (Whistler, 1993; Saulnier et al. 1995b; Carvajal-Millan et al., 2007) or acid solutions (Saulnier et al., 1995a) to produce water-soluble AX. Wheat bran contains approximately $19 \%$ of water-insoluble AX, which can be extracted with alkaline or acid solutions to produce water-soluble AX (Hashimoto et al., 1987). 
This chapter includes some of the most recent findings on physico-chemical and functional properties of water-soluble ferulated arabinoxylans from three cereal by-products: nejayote (nixtamalization waste water), maize bran and wheat bran.

\section{Experimental}

\subsection{Materials and methods}

Nejayote, maize bran and wheat bran were kindly provided by commercial milling industries in Northern Mexico. All chemical products were purchased from Sigma Chemical Co. (St Louis, MO, USA).

\subsection{Arabinoxylans extraction}

AX from nejayote (FAXN) and AX from maize bran (FAXMB) presented in this study were previously extracted and characterized (Carvajal-Millán et al. 2007; Niño-Medina (2009)).

AX from wheat bran (FAXWB) were extracted as follows. Wheat bran was ground to a 20mesh particle size using a M20 Universal Mill (IKA®, Werke Staufen, Germany). Wheat bran $(500 \mathrm{~g})$ was treated with ethanol $(2500 \mathrm{ml})$ for $12 \mathrm{~h}$ at $25^{\circ} \mathrm{C}$ to remove lipophilic components.

The ethanol treated bran was then filtered and subjected to starch gelatinization and enzymes inactivation (boiling for $30 \mathrm{~min}$ in $3500 \mathrm{ml}$ of water). After boiling, wheat bran was recovered by filtration and treated with $2500 \mathrm{ml}$ of $\mathrm{NaOH} 0.5 \mathrm{~N}$ solution at $25^{\circ} \mathrm{C}$ in darkness for $1 \mathrm{~h}$ under shake (100 rpm). Residual bran was then eliminated by filtration and the filtrate was centrifuged $\left(12,096 \mathrm{~g}, 20^{\circ} \mathrm{C}, 15 \mathrm{~min}\right)$.

Supernatant was acidified to $\mathrm{pH} 4$ with $\mathrm{HCl} 3 \mathrm{~N}$. Acidified liquid was centrifuged $(12,096 \mathrm{~g}$, $20{ }^{\circ} \mathrm{C}, 15 \mathrm{~min}$ ) and supernatant was then recuperated and precipitated in $65 \%$ (v/v) ethanol for $4 \mathrm{~h}$ at $4^{\circ} \mathrm{C}$. Precipitate was recovered and dried by solvent exchange $(80 \%$ (v/v) ethanol, absolute ethanol and acetone) to give FAXWB.

\subsection{Chemical composition of FAXWB}

Sugar composition was determined according to Carvajal-Millan et al. (2007) after FAXWB hydrolysis with $2 \mathrm{~N}$ trifluoroacetic acid at $120^{\circ} \mathrm{C}$ for $2 \mathrm{~h}$. The reaction was stopped on ice, the extract was evaporated under air at $40{ }^{\circ} \mathrm{C}$ and rinsed twice with $200 \mu \mathrm{L}$ of water and resuspended in $500 \mu \mathrm{L}$ of water.

All samples were filtered through $0.45 \mu \mathrm{m}$ (Whatman) and analyzed by high performance liquid chromatography (HPLC) using a Supelcogel Pb column $(300 \times 7.8 \mathrm{~mm}$; Supelco, Inc., Bellefont, PA) eluted with $5 \mathrm{mM} \mathrm{H}_{2} \mathrm{SO}_{4}$ (filtered $0.2 \mu \mathrm{m}$, Whatman) at $0.6 \mathrm{~mL} / \mathrm{min}$ and $50{ }^{\circ} \mathrm{C}$. A refractive index detector Star 9040 (Varian, St. Helens, Australia) and a Star Chromatography Workstation system control version 5.50 were used. The internal standard was inositol.

Ferulic acid was quantified by high performance liquid chromatography (HPLC) after deesterification step as described by Vansteenksite et al., (2004). An Alltima $\mathrm{C}_{18}$ column (250 $\times 4.6 \mathrm{~mm})($ Alltech associates, Inc. Deerfield, IL) and a photodiode array detector Waters 996 (Millipore Co., Milford, MA) were used. Detection was by UV absorbance at $320 \mathrm{~nm}$.

Ash content was determined according to the AACC methods (AACC, 1998). Protein was determined by using the Bradford method (Bradford, 1976). 


\subsection{Intrinsic viscosity of FAXWB}

Specific viscosity, $\eta \mathrm{sp}$ was measured by registering FAXWB solutions flow time in an Ubbelohde capillary viscometer at $25 \pm 0.1^{\circ} \mathrm{C}$, immersed in a temperature controlled bath. FAXWB solutions were prepared at different concentrations, dissolving dried polysaccharide in water for $10 \mathrm{~h}$ with stirring at room temperature. FAXWB solutions and water were filtered using $0.45 \mu \mathrm{m}$ membrane filters before viscosity measurements.

The intrinsic viscosity $([\eta])$ was estimated from relative viscosity measurements, prel, of FAXWB solutions by extrapolation of Kraemer and Mead and Fouss curves to "zero" concentration.

\subsection{Viscosimetric molecular weight of FAXWB}

The viscosimetric molecular weight $(\mathrm{Mv})$ was calculated from the Mark-Houwink relationship, $\mathrm{Mv}=([\eta] / \mathrm{k}) 1 / \mathrm{a}$.

\subsection{FAXN, FAXMB and FAXMB gelation}

FAXN, FAXMB and FAXWB solutions $(4,3.5$ and $5.0 \% \mathrm{w} / \mathrm{v})$ were prepared in $0.05 \mathrm{M}$ citrate phosphate buffer $\mathrm{pH}$ 5. Laccase ( $1.675 \mathrm{nkat}$ per $\mathrm{mg}$ polysaccharide) was used as gelling agent. Gels were allowed to form at $25^{\circ} \mathrm{C}$.

\subsection{Small deformation measurements}

The formation of FAXN, FAXMB and FAXWB gels was followed using a strain-controlled rheometer (AR-1500ex, TA Instruments, U.S.A.) in oscillatory mode as follows. Cold $\left(4{ }^{\circ} \mathrm{C}\right)$ solutions of FAXN, FAXMB and FAXWB at 4, 3.5 and 5.0\%, respectively (w/v) were mixed with laccase (1.675 nkat per mg polysaccharide) and immediately placed in the cone and plate geometry $\left(5.0 \mathrm{~cm}\right.$ in diameter, $0.04 \mathrm{rad}$ in cone angle) maintained at $4{ }^{\circ} \mathrm{C}$.

Exposed edges of the sample were covered with silicone fluid to prevent evaporation during measurements. Gelation kinetic was started by a sudden increase in temperature from $4{ }^{\circ} \mathrm{C}$ to $25{ }^{\circ} \mathrm{C}$ and monitored at $25^{\circ} \mathrm{C}$ over time by following the storage $\left(\mathrm{G}^{\prime}\right)$ and loss $\left(\mathrm{G}^{\prime \prime}\right)$ modulus.

All measurements were carried out at a frequency of $0.25 \mathrm{~Hz}$ and $5 \%$ strain (linearity range of viscoelastic behavior). Frequency sweep $(0.1$ to $50 \mathrm{~Hz})$ was carried out at the end of the network formation at $5 \%$ strain and $25^{\circ} \mathrm{C}$.

\subsection{Large deformation measurements}

The hardness of FAXN, FAXMB and FAXWB gels was analyzed with a TA.XT2 Texture Analyzer (RHEO Stable Micro Systems, Haslemere, England) equipped with a XTRAD software version 3.7 .

The gels were deformed by compression at a constant speed of $1.0 \mathrm{~mm} / \mathrm{s}$ to a distance of 4 $\mathrm{mm}$ from the gel surface using a cylindrical plunger (diameter $25.4 \mathrm{~mm}$ ). The peak height at $4 \mathrm{~mm}$ compression was called gel hardness (Carvajal-Millan et al., 2005a).

\subsection{Gel swelling}

After laccase addition, FAXN, FAXMB and FAXWB solutions were quickly transferred to a $5 \mathrm{ml}$ tip-cut-off syringe (diameter $1.5 \mathrm{~cm}$ ) and allowed to gelify for $2 \mathrm{~h}$ at $25^{\circ} \mathrm{C}$. After gelation, the gels were removed from the syringes, placed in glass vials and weighted. 
The gels were allowed to swell in $20 \mathrm{ml}$ of $0.02 \%$ (w/v) sodium azide solution to prevent microbial contamination. During $20 \mathrm{~h}$ the samples were blotted and weighed. After weighing, a new aliquot of sodium azide solution was added to the gels. Gels were maintained at $25^{\circ} \mathrm{C}$ during the test.

The equilibrium swelling was reached when the weight of the samples changed by no more than $3 \%(0.06 \mathrm{~g})$. The swelling ratio $(\mathrm{q})$ was calculated as:

$$
\mathrm{q}=(\mathrm{Ws}-\mathrm{Wd}) / \mathrm{Wd}
$$

where Ws is the weight of swollen gels and Wd is the weight of polysaccharide in the gel.

\subsection{Gel structure}

From swelling measurements, the molecular weight between two cross-links (Mc), the crosslinking density $(\rho c)$ and the mesh size $(\xi)$ values of the FAXN, FAXMB and FAXWB gels were obtained as reported by Carvajal-Millan et al. (2005b). Mc, $\rho c$ and $\xi$ were calculated using the model of Flory and Rehner modified by Peppas and Merrill for gels where the cross-links are introduced in solution.

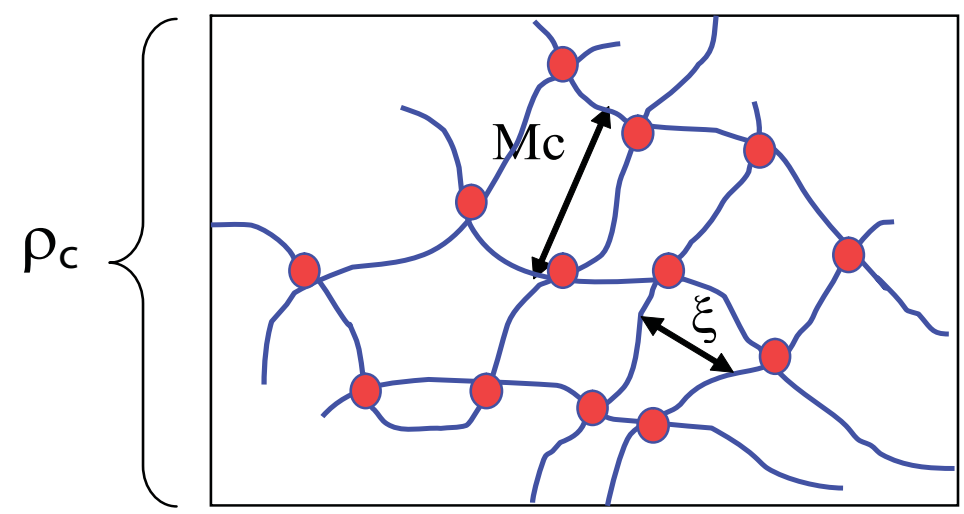

Fig. 1. Schematic representation of gel structural parameters. Mc=Molecular weight between two cross-links, $\rho c=$ cross-linking density and $\varepsilon=$ mesh size.

\section{Results and discussion}

In a previous report, FAXN and FAXMB have been extracted and characterized NiñoMedina (2009). Yield of FAXN and FAXMB were 8 (w FAXN/v nejayote) and $29 \%$ (w FAXMB/w maize bran), respectively.

In FAXN, pure arabinoxylans represented $81 \%$ dry basis $(\mathrm{db})$ of the recovered sample (Table 1). This value was estimated from the sum of xylose + arabinose. The ratio arabinoseto-xylose $(\mathrm{A} / \mathrm{X})$ was 0.65 indicating a moderately branched structure, similar to that reported by Singh et al. (2000) in maize bran arabinoxylans. Residues of glucose, galactose, mannose, proteins and ash were also detected in FAXN.

The ferulic acid content, $[\eta]$ and $\mathrm{Mw}$ values were lower to those reported for ferulated arabinoxylans from other sources (Izydorczyk et al., 1990; Dervilly-Pinel et al., 2001; Vansteenkiste et al., 2004; Carvajal-Millan et al., 2006). 


\begin{tabular}{ll}
\hline Arabinose (\%) & $33.0 \pm 0.70$ \\
Xylose (\%) & $39.0 \pm 1.20$ \\
Glucose (\%) & $4.90 \pm 0.15$ \\
Galactose (\%) & $3.90 \pm 0.11$ \\
Mannose (\%) & $0.60 \pm 0.04$ \\
Protein (\%) & $2.70 \pm 0.20$ \\
Ash (\%) & $3.58 \pm 0.14$ \\
Ferulic acid (\%) & $0.003 \pm 0.05$ \\
A/X (mass ratio) & $0.85 \pm 0.20$ \\
[ๆ] (mL/g) & $208 \pm 6.2$ \\
\hline
\end{tabular}

Table 1. Composition of ferulated arabinoxylans from nejayote (FAXN) (adapted from NiñoMedina (2009)).

As presented in Table 2, FAXMB presented an arabinoxylan content of $72 \%$ (w/w), a ferulic acid content of $0.003(\% \mathrm{w} / \mathrm{w})$, an $\mathrm{A} / \mathrm{X}$ ratio of 0.85 , an intrinsic viscosity $[\eta]$ of $208 \mathrm{~mL} / \mathrm{g}$ and a molecular weight $(\mathrm{Mw})$ of $190 \mathrm{kDa}$.

\begin{tabular}{ll}
\hline Arabinose (\%) & $32.0 \pm 0.80$ \\
Xylose (\%) & $49.0 \pm 1.90$ \\
Glucose (\%) & $5.10 \pm 0.40$ \\
Galactose (\%) & $3.70 \pm 0.20$ \\
Mannose (\%) & $0.60 \pm 0.04$ \\
Protein (\%) & $4.50 \pm 0.20$ \\
Ash (\%) & $5.10 \pm 0.21$ \\
Ferulic acid (\%) & $0.002 \pm 0.01$ \\
A/X (mass ratio) & $0.65 \pm 0.10$ \\
{$[\eta](\mathrm{mL} / \mathrm{g})$} & $183 \pm 5.4$ \\
Mw (kDa) & $60 \pm 6.0$ \\
\hline
\end{tabular}

Table 2. Composition and physico-chemical characteristics of ferulated arabinoxylans from maize bran (FAXMB) (adapted from Niño-Medina (2009)).

The higher ferulic acid content and $[\eta]$ and Mw values in FAXMB in comparison with FAXN could be attributed to the differences in the extractions conditions used. FAXN are recovered after maize nixtamalization which consists of cooking maize grains in a lime solution, after soaking for 2 to 8 hours while FAXMB are alkali-extracted under mild conditions ( $\mathrm{NaOH} 0.5 \mathrm{~N}$ solution at $25^{\circ} \mathrm{C}$ in darkness for $8 \mathrm{~h}$ ).

In this chapter is presented for the first time the extraction and characterization of FAXWB. FAXWB yield was $17 \%$ (w FAXWB/w wheat bran), which is higher than the value previously reported for FAXN (8\% w/v) but lower than that found for FAXMB $(29 \% \mathrm{w} / \mathrm{w})$. Composition of FAXWB is presented in Table 3. Arabinoxylan (AX) represented $76 \%$ dry basis $(\mathrm{db})$ of the recovered FAXWB. This value was estimated from the sum of xylose + arabinose. This arabinoxylan content is in the range found for FAXN and FAXMB (86 and 72 $\%$, respectively).

The ratio arabinose-to-xylose was high $(\mathrm{A} / \mathrm{X}=0.80)$ indicating a highly branched structure, similar to that reported by Schooneveld-Bergmans et al. (1999) in wheat bran arabinoxylans. A high $\mathrm{A} / \mathrm{X}$ ratio was also found in FAXMB (0.85) in comparison to the moderate $\mathrm{A} / \mathrm{X}$ value found in FAXN (0.65). 


\begin{tabular}{|c|c|}
\hline Arabinose (\%) & $33.00 \pm 1.20$ \\
\hline Xylose (\%) & $43.00 \pm 1.30$ \\
\hline Glucose (\%) & $3.10 \pm 0.40$ \\
\hline Galactose (\%) & $2.10 \pm 0.30$ \\
\hline Mannose (\%) & $0.30 \pm 0.03$ \\
\hline Protein (\%) & $2.70 \pm 0.20$ \\
\hline Ash (\%) & $2.30 \pm 0.21$ \\
\hline Ferulic acid (\%) & $0.0050 \pm 0.05$ \\
\hline $\mathrm{A} / \mathrm{X}$ (mass ratio) & $0.80 \pm 0.40$ \\
\hline [n] $(\mathrm{mL} / \mathrm{g})$ & $198 \pm 5.6$ \\
\hline Mw (kDa) & $60 \pm 3.0$ \\
\hline
\end{tabular}

Table 3. Composition of ferulated arabinoxylans from wheat bran (FAXWB)

These differences in $\mathrm{A} / \mathrm{X}$ ratio could explain the higher water solubility of FAXN as arabinose residues increase the molecule hydrophilic characteristic. As in FAXN and FAXMB, residues of glucose, galactose, mannose, proteins and ash were detected in FAXWB. The ferulic acid content $(0.005 \%)$ was higher in FAXWB than in FAXN and FAXMB but lower than that obtained by Schooneveld-Bergmans et al. (1999) in wheat bran arabinoxylans recovered by using a different extraction method.

The intrinsic viscosity $([\eta])$ and a molecular weight $(\mathrm{Mw})$ values in FAXWB were $168 \mathrm{~mL} / \mathrm{g}$ and $60 \mathrm{kDa}$, respectively, which are in the range found in FAXN and FAXMB. Due their different nature, the ferulated arabinoxylans extracted from each low-value maize and wheat by-product showed different yield, composition and physico-chemical characteristics. FAXN and FAXMB have been reported to form covalent gels in presence of a laccase. According to Niño-Medina (2009), treatment of FAXN with laccase as oxidizing agent formed a gel after $4-6$ hours at $25^{\circ} \mathrm{C}$.

The formation of $4 \%(\mathrm{w} / \mathrm{v})$ FAXN gels over time was rheologically investigated by small amplitude oscillatory shear. These authors found that the storage $\left(G^{\prime}\right)$ and loss $\left(G^{\prime \prime}\right)$ modulus rose over the time to reach a plateau with a final $\mathrm{G}^{\prime}$ value of $2 \mathrm{~Pa}$, which is lower than those reported for arabinoxylan gels from other sources $(20-40 \mathrm{~Pa})$ at lower polysaccharide concentrations (1-2\% w/v) (Carvajal-Millán et al., 2005a). On the other hand, a final $\mathrm{G}^{\prime}$ value of $20 \mathrm{~Pa}$ was found in 3.5\% (w/v) FAXMB (Berlanga-Reyes et al., 2009) after gelation by a laccase.

Concerning FAXWB, during laccase induced gelation $G^{\prime}$ modulus rose to reach a plateau (Fig. 1). The final $\mathrm{G}^{\prime}$ value was $177 \mathrm{~Pa}$ in a 5\% (w/v) FAXWB gel.

The mechanical spectrum of FAXWB gel is presented in Fig. 2. After 90 minutes gelation spectrum was typical of solid-like materials with a linear $G^{\prime}$ independent of frequency and $G^{\prime \prime}$ much smaller than $G^{\prime}$ and dependent on frequency (Doublier \& Cuvelier, 1996). This behavior is similar to that previously reported for other arabinoxylan gels cross-linked by laccase or peroxidase $/ \mathrm{H}_{2} \mathrm{O}_{2}$ system (Izydorczyk et al., 1990; Dervilly-Pinel et al., 2001; Vansteenkiste et al., 2004; Carvajal-Millan et al., 2006).

The hardness of FAXN, FAXMB and FAXWB gels are presented in Fig. 3. In agree with small deformation rheological results $\left(G^{\prime}, G^{\prime \prime}\right)$ discussed above, large deformation measurements (gel hardness) showed that FAXWB can form gels more elastic than those from FAXN and FAXMB. 


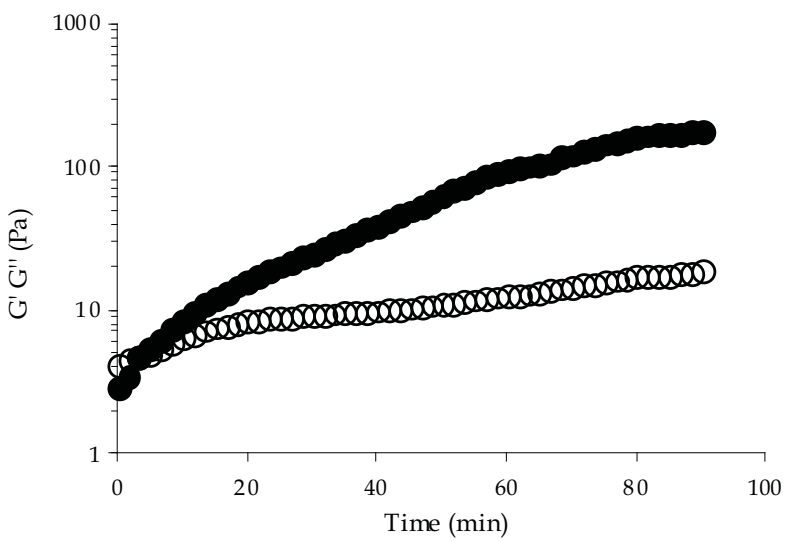

Fig. 1. Laccase induced gelation of FAXWB solutions at $5 \%(w / v)\left(G^{\prime} \bullet, G^{\prime \prime} 0\right)$. Rheological measurements made at $25^{\circ} \mathrm{C}, 0.25 \mathrm{~Hz}$ and $5 \%$ strain.

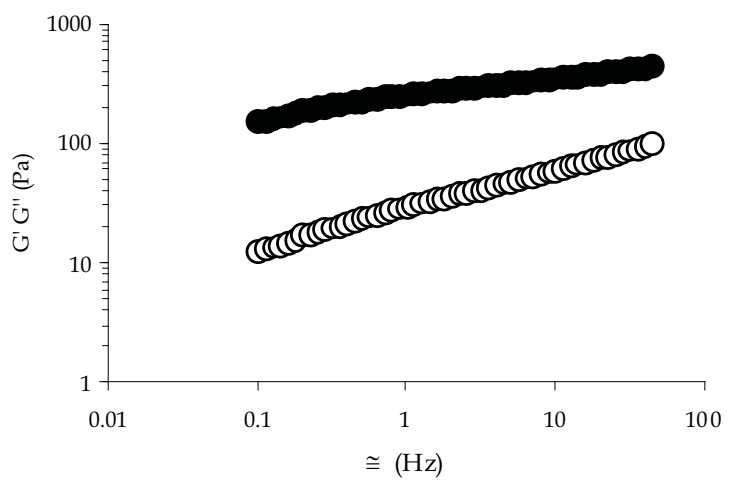

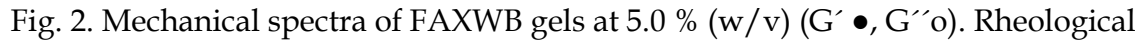
measurements made at $25^{\circ} \mathrm{C}$ and $5 \%$ strain.

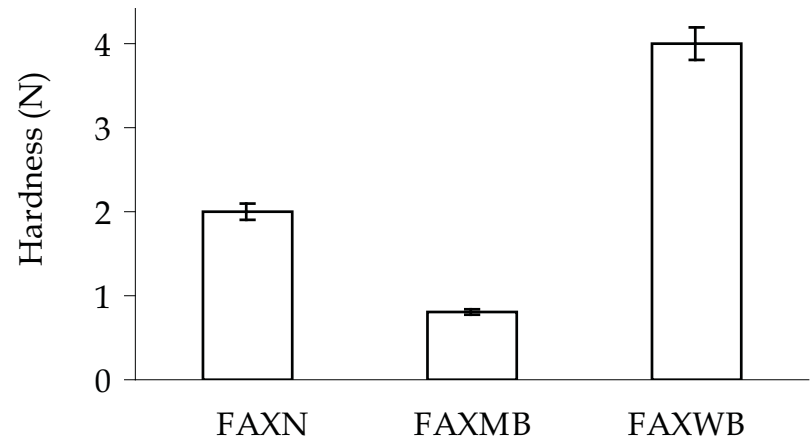

Fig. 3. Hardness of FAXN, FAXMB and FAXWB gels at 4, 3.5 and $5.0 \%(w / v)$, respectively. Rheological measurements made at $25^{\circ} \mathrm{C}$. 
The rheological differences between FAXN, FAXMB and FAXWB gels might have its origin in the structural and/or conformational characteristics of these macromolecules. Clearly, further studies on the distribution of arabinose and feruloyl groups along the polymer chain backbone of these different arabinoxylans are needed to establish relationships between the molecular structure, gelling ability and gels properties.

The equilibrium swelling of FAXN, FAXMB and FAXWB gels was reached between 15-20 h. The swelling ratio ( $\mathrm{q}, \mathrm{g}$ water/g polysaccharide) in FAXN, FAXMB and FAXWB gels were 40, 22 and 20, respectively (Table 4).

\begin{tabular}{lllll}
\hline AX Source & $\begin{array}{l}\text { Swelling ratio } \\
(\mathrm{q}, \text { g water/g AX) }\end{array}$ & $\begin{array}{l}\mathrm{M}_{\mathrm{c}} \mathrm{a} \times 10^{3} \\
(\mathrm{~g} / \mathrm{mol})\end{array}$ & $\begin{array}{l}\rho_{\mathrm{c}}{ }^{\mathrm{b}} \times 10^{-6} \\
\left(\mathrm{~mol} / \mathrm{cm}^{3}\right)\end{array}$ & $\begin{array}{l}\varepsilon^{\mathrm{c}} \\
(\mathrm{nm})\end{array}$ \\
\hline FAXN & $40+1.5$ & $95+0.1$ & $9.0+0.01$ & $183+4$ \\
FAXMB & $22+1.9$ & $20+0.1$ & $75+0.01$ & $48+1$ \\
FAXWB & $20+1.7$ & $29+0.1$ & $59+0.01$ & $58+1$ \\
\hline
\end{tabular}

a Molecular weight between two cross-links

b Cross-linking density

c Mesh size

Table 4. Structural characteristics of FAXN, FAXMB and FAXWB gels.

The lower swelling ratio values obtained for FAXMB and FAXWB can be related to the more compact polymeric structure that limits the water absorption in comparison to the FAXN gels. The higher water uptake of gels made from FAXN can be explained in terms of a decrease in ferulic acid content and therefore the existence of longer un-cross-linked polysaccharide chains sections in the network. Uncross-linked polymer chains sections in the gel can expand easily conducting to higher amounts of water uptake.

The molecular weight between two cross-links (Mc), the cross-linking density $(\rho c)$ and the mesh size $(\xi)$ values of the different gels are presented in Table 3. Higher Mc and $\xi$ and lower $\rho c$ values have been reported in laccase induced water soluble arabinoxylan gels from wheat at similar AX concentrations (Carvajal-Millan et al., 2005b).

The latter could be related to a high molecular weight in arabinoxylans from wheat endosperm (400-600 kDa) in comparison to alkali-extracted arabinoxylans from maize and wheat bran (60-240 kDa) used in the present study. The involvement of physical interactions between polysaccharide chains could also be responsible of these differences. Different arabinoxylan gel structural characteristics were therefore obtained by modifying the polysaccharide source (FAXN, FAXMB, FAXWB).

The results discussed above indicate that by changing the arabinoxylan source gels with different rheological and structural properties can be obtained. To illustrate how the possible covalent cross-links content in the gel can affect network structure, we propose in Fig. 4 a model of the FAXN, FAXMB and FAXWB gels. As showed in Fig. 4 a decrease in the initial ferulic acid content could decrease the covalent bonds content. These differences in the network structure could induce changes in the functional properties of the gel. 


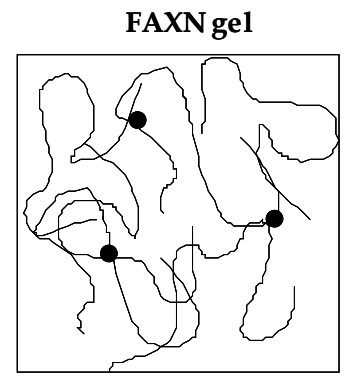

FAXMB gel

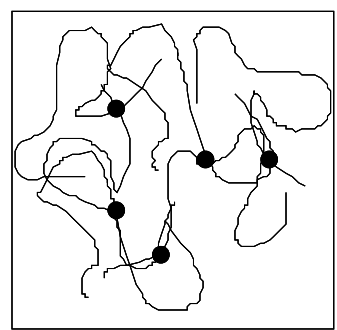

FAXWB ge1

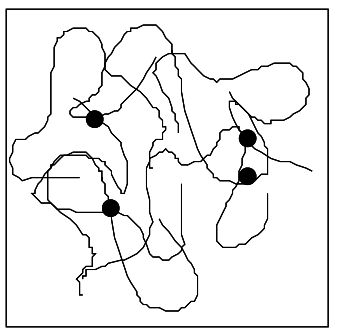

Fig. 4. Schematic representation of FAXN, FAXMB and FAXWB gels.

\section{Conclusion}

Nejayote (a maize processing waste water), maize bran and wheat generated from flour industries can be potential sources of ferulated arabinoxylans as added-value hydrocolloids for the food industry. Due their different nature, the arabinoxylans extracted from each showed different physico-chemical and gelling properties. Recuperation of these hydrocolloids from low-value maize and wheat by-products could represent a commercial advantage face to other polysaccharides commonly used in the food industry.

\section{Future considerations}

New sources of polysaccharides continue to be investigated and different functional properties are being discovered. Concerning ferulated arabinoxylans from low-value lowvalue maize and wheat by-products, several questions remained to be elucidated, especially 
those concerning the relationships between the molecular structure, gelling ability and gels properties.

Additional studies will also be required on the application of these polysaccharides in food products. In this regard, technological and nutritional evaluation of these food products would be necessary. FAXN, FAXMB and FAXWB would have health benefits such as lowering of blood cholesterol and sugar as well as antioxidants properties but complementary studies are required.

\section{Acknowledgements}

Some of the results presented in this contribution are part of a research project supported by Fondo Institucional SEP-CONACYT, Mexico (grant 61287 to E. Carvajal-Millan). The authors are pleased to acknowledge Kevin Hicks (Eastern Regional Research Center, NAA, ARS, USDA), Valerie Micard (SupAgro Montpellier, France) and Mirko Bunzel (University of Minnesota, U.S.) for their participation in this research project. The authors are grateful to Alma C. Campa and Karla Martínez for their technical assistance.

\section{References}

AACC. (1998). In: Approved Methods of the American Association of Cereal Chemists, The Association. Minnesota, USA.

Andrewartha, K. A., Phillips, D. R. \& Stone, B. A. (1979). Solution properties of wheat-flour arabinoxylans and enzimatically modified arabinaoxylans. Carbohydrate Research, 77, 191-204.

Berlanga-Reyes, C., Carvajal-Millán, E., Caire-Juvera, G., Rascón-Chu, AS. MarquezEscalante, J.A. \& Martínez-López, A.L. (2009). Laccase induced maize bran arabinoxylan gels: structural and rheological properties. Journal of Food Science and Biotechnology, 18, 1027-1029.

Bradford, M. (1976). A rapid and sensitive method for the quantification of microgram quantities of protein utilizing the principle of protein-dye binding. Analytical Biochemistry, 72, 248-254.

Carvajal-Millán, E., Landillon, V., Morel, M.H., Rouau, X., Doublier, J.L., Micard, V. (2005b). Arabinoxylan gels: impact of the feruloylation degree on their structure and properties. Biomacromolecules, 6, 309-317.

Carvajal-Millán, E., Guigliarelli, B., Belle, V., Rouau, X. \& Micard, V. (2005a). Storage stability of arabinoxylan gels. Carbohydrate Polymers, 59, 181-188.

Carvajal-Millán, E., Guilbert, S., Doublier, J. L. \& Micard, V. (2006). Arabinoxylan/protein gels: structural, rheological and controlled release properties. Food Hydrocolloids, 20, 53-61.

Carvajal-Millán, E., Rascón-Chu, A., Márquez-Escalante, J. Ponce de León, N., Micard, V. \& Gardea, A. (2007). Maize bran gum: characterization and functional properties. Carbohydrate Polymers, 69, 280-285.

Cui S. W. 2001. Chapter 4. Cereal non-starch polysaccharides II: Pentosans/Arabinoxylans. Polysacharide gums from agricultural products. Processing, structures and functionality. Lancaster, Penn. Technomic Publishing Company. pp. 167-227.

Dervilly-Pinel, G., Rimsten, L., Saulnier, L., Andersson, R. \& Åman, P. (2001). Waterextractable arabinoxylan from pearled flours of wheat, barley, rye and triticale. Evidence for the presence of ferulic acid dimmers and their involvement in gel formation. Journal of Cereal Science, 34, 207-214. 
Doublier, J.L., Cuvelier, G. Gums and hydrocolloids: functional aspects. Vol. I, pp. 283-318. In: Carbohydrates in Food. Eliasson, A.C. (ed). Marcel Dekker, New York:, USA. (1996).

Figueroa-Espinoza, M. C. \& Rouau, X. (1998). Oxidative cross-linking of pentosans by a fungal laccase and a horseradish peroxidase: mechanism of linkage between feruloylated arabinoxylans. Cereal Chemistry, 75, 259-265.

Fincher, G. B. \& Stone, B. A. (1974). A water-soluble arabinogalactan-peptide from wheat endosperm. Australian Journal of Biological Science, 27, 117-132.

Geissman, T. \& Neukom, H. (1973). On the composition of the water-soluble wheat flour pentosanes and their oxidative gelation. Lebensmittel-Wissenchaft-und-Technologie, 6, $59-62$.

Hashimoto, S., Shogren, M.D. \& Pomeranz, Y. (1987) Cereal pentosans: their estimation and significance. III. Pentosans in abraded grains and miling products of wheat and milled wheat products. Cereal Chemistry, 64, 39-41.

Hespell, R.B. (1998). Extraction and characterization of hemicellulose from the corn fiber produced by corn wet-milling processes. Journal of Agriculture Food Chemistry, 46, 2615-2619.

Ishii, T. 1991. Isolation and characterization of a diferuloyl arabinoxylan hexasaccharide from bamboo shoot cell walls. Carbohydrate Research. 219: 15-22.

Izydorczyk, M. S. \& Biliaderis, C. G. (1995). Cereal arabinoxylans: advances in structure and physicochemical properties. Carbohydrate Polymers, 28, 33-48.

Izydorczyk, M. S., Biliaderis C. G. \& Bushuk, W. (1990). Oxidative gelation studies of watersoluble pentosans from wheat. Journal of Cereal Science, 11, 153-169.

Lapierre, C., Pollet, B., Ralet, M. C. \& Saulnier, L. (2001). The phenolic fraction of maize bran: evidence for lignin-heteroxylan association. Phytochemistry, 57, 765-772.

Niño-Medina, G., Carvajal-Millán, E., Rascón-Chu, A., Lizardi, J., Márquez-Escalante, J., Gardea, A., Martínez-López, A.L. \& Guerrero, V. (2009b). Maize processing waste water arabinoxylans: gelling capability and cross-linking content. Food Chemistry, $115,1286-1290$.

Niño-Medina, G. (2009). Gelling capability of ferulated arabinoxylans from maize byproducts. PhD Dissertation, Center for Food and Development, CIAD, A.C. Mexico.

Saulnier, L., Marot, C., Chanliaud, E., \& Thibault, J.-F. (1995b). Cell wall polysaccharide interactions in maize bran. Carbohydrate Polymer, 26, 279-287.

Saulnier, L., Vigouroux, J., \& Thibault, J.-F. (1995a). Isolation and partial characterization of feruloylated oligosaccharides from maize bran. Carbohydrate Research, 272, 241-253.

Schooneveld-Bergmans, M. E. F., Dignum, M. J. W., Grabber, J. H., Beldman, G. \& Voragen, A. G. J. (1999). Studies on the oxidative cross-linking of feruloylated arabinoxylans from wheat flour and wheat bran. Carbohydrate Polymers, 38, 309-317.

Singh, V., Doner, L.W., Johnston, D.B., Hicks, K. B. \& Eckhoff, S.R. (2000). Comparison of coarse and fine corn fiber for corn fiber gum yields and sugar profiles. Cereal Chemistry, 77, 560-561.

Smith, M. M. \& Hartley, R. D. (1983). Occurrence and nature of ferulic acid substitution of cell-wall polysaccharides in graminaceous plants. Carbohydrate Research, 118, 65-80.

Vansteenkiste, E., Babot, C., Rouau, X. \& Micard, V. (2004). Oxidative gelation of feruloylated arabinoxylan as affected by protein. Influence on protein enzymatic hydrolysis. Food Hydrocolloids, 18, 557-564.

Whistler, R. L. (1993). Hemicelluloses. In R. L. Whistler \& J. N. BeMiller (Eds.), Industrial gums, polysaccharides and their derivatives (pp. 295-308). Orlando: Academic Press. 


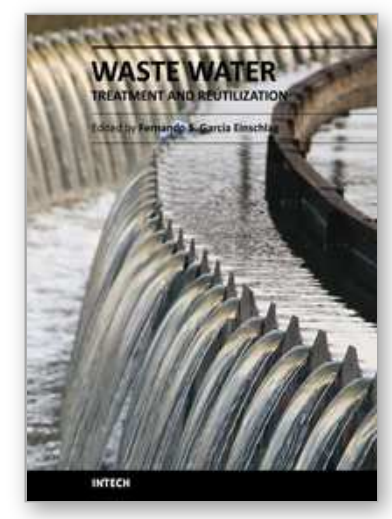

\author{
Waste Water - Treatment and Reutilization \\ Edited by Prof. Fernando Sebastiẽ $i n$ GarcÃa Einschlag
}

ISBN 978-953-307-249-4

Hard cover, 434 pages

Publisher InTech

Published online 01, April, 2011

Published in print edition April, 2011

The steady increase in industrialization, urbanization and enormous population growth are leading to production of huge quantities of wastewaters that may frequently cause environmental hazards. This makes waste water treatment and waste water reduction very important issues. The book offers a collection of studies and findings concerning waste water treatment, minimization and reuse.

\title{
How to reference
}

In order to correctly reference this scholarly work, feel free to copy and paste the following:

Claudia Berlanga-Reyes, Elizabeth Carvajal-Millan, Guillermo Niño-Medina, Agustín Rascón-Chu, Benjamín Ramírez-Wong and Elisa Magaña-Barajas (2011). Low-Value Maize and Wheat By-Products as a Source of Ferulated Arabinoxylans, Waste Water - Treatment and Reutilization, Prof. Fernando Sebastî̃ Einschlag (Ed.), ISBN: 978-953-307-249-4, InTech, Available from: http://www.intechopen.com/books/wastewater-treatment-and-reutilization/low-value-maize-and-wheat-by-products-as-a-source-of-ferulatedarabinoxylans

\section{INTECH}

open science | open minds

\section{InTech Europe}

University Campus STeP Ri

Slavka Krautzeka 83/A

51000 Rijeka, Croatia

Phone: +385 (51) 770447

Fax: +385 (51) 686166

www.intechopen.com

\section{InTech China}

Unit 405, Office Block, Hotel Equatorial Shanghai

No.65, Yan An Road (West), Shanghai, 200040, China

中国上海市延安西路65号上海国际贵都大饭店办公楼 405 单元

Phone: +86-21-62489820

Fax: $+86-21-62489821$ 
(C) 2011 The Author(s). Licensee IntechOpen. This chapter is distributed under the terms of the Creative Commons Attribution-NonCommercialShareAlike-3.0 License, which permits use, distribution and reproduction for non-commercial purposes, provided the original is properly cited and derivative works building on this content are distributed under the same license. 